\title{
Книга Білцаревы під редакцийом Петра Трохановского
}

\section{Крениця-Горлиці-Білцарева 2017'}

Лемкознавча і лемкоязычна бібліотека збогатила ся в 2017 р. барз цінном книжком. Ба, не тильо книжком, што Книгом - і так ся тіж она зове: Книга Білцаревы. Мала то в задумі быти, з того што знам, монографія нашого села, Білцаревы (пишу нашого, хоц я ся вродил на Заході, та мимо того оно для ня все буде наше), але вышло штоси дуже векше і важніжше як лем монографія єдного села.

На початок жменя сухых даных: формат A-4, тверда окладинка, 580 сторін на кредовым папері о граматурі, на моє око, 120. Зміст поділений на 6 розділив:

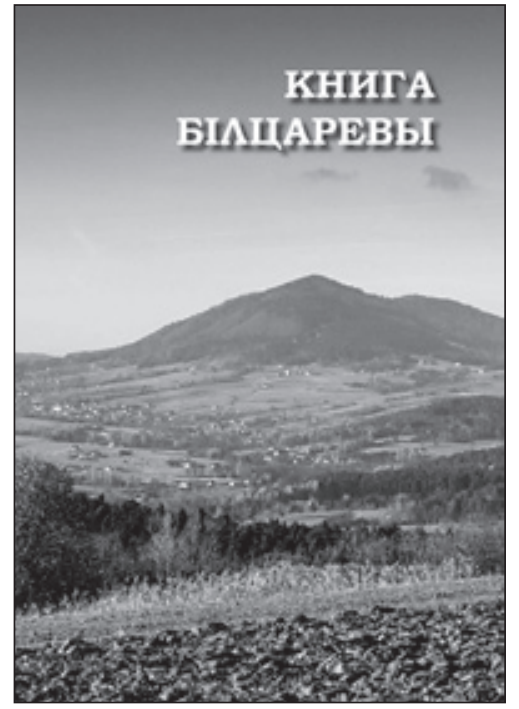

1 В сесым тексті, одмінні од стосуваной в «Річнику Руской Бурсы» едиторско-коректорской практыкы, не вводиме ниякых орфографічных і лексикальных корект. Автором рецензиі єст бо творця Словника лемкківско-польского/польско-лемківского, котрого концепциі языковой нормы не хочеме нарушати (прип. ред.). 
1. Част вступна - 7 сторін;

2. Геограбія - 30 сторін;

3. Істория - 187 сторін, поділена на підрозділы: Праістория, Середньовіча, Середньовічна Білиарева, Новожытна Білиарева, Під Австрийом, Білцарівска емігращия, Зас під Польщзом;

4. Духова, матеріальна і соспільна культура - 56 сторін;

5. Знатны люде, білиарівскы твориі - 166 сторін;

6. На выгнаню - 71 сторін.

Поза тым єст в ній понад 450 знимок, гнешніх (кольоровых) i apxiвальных (чорно-білых), як тіж понад 100 інчого роду ілюстраций і репродукций, мапок, табель, аж і пару ікон. Похоснувана література обнимат 106 позиций, а архівальны документы - 145 позиций.

Головні в части історичний, але не лем, стороны сут поділены на част головну і шырокы маргінесы на якых, дрибніжшым шрифтом, поміщены сут ноткы, часто цитаты, з книжок, документив і інчых жерельных матерялив на потверджыня представленых інформаций. Поза тым - ту позволю си зацитувати Автора: «вміщат в собі - похоснуваны окремо, або серед розділів трактуючых о істориі і матеріальній культурі - творы і дописы» - і ту подано 21 назвиск, в тым 13, якых юж неє серед жывых. Серед тых, котры вспомогли Книгу... інчыма матерялами - фотографіями, документами, розповідями, інформациями, подано 45 осиб, з котрых тіж юж 16 вснуло сном вічным. Помочом практычном служыло 11 осиб. Не буду ту выріжнял никого, поза єдным чловеком - Петром Басалыгом, якого добрі понад 100 чудовых фотографій єст в Книзі... і якій помагал Авторови і в інчий спосиб. Під наголовком написано «під редакцийом Петра Трохановского». De facto Він $є$ автором того діла, а не лем редактором. В части: Духова, матеріальна і соспільна культура ведучий текст написал Богдан Гамбаль, а матерялы дал Петро Трохановскій. Книга... обнимат і еміграцию, так на Всхід - на тилько, на кілько удало ся зобрати, як і на Захід.

Знал єм, же Трохановскій працує над том монографійом і знал єм, знаючы Його, же то буде велика річ під каждым взглядом, але коли єм дистал пресылку з Руской Бурсы, та єм ся зачудувал. Кількіст зобраного матерялу, спосиб його представліня, кількіст інформаций і знимок єст задивляюча. Вартат звернути увагу, же коли гнеска дахто бы задумал таку монографію писати, та з помочы найважніжшых для той книгы (не жыючых уж) осиб не міг бы юж скорыстати - а сут то інформациі 
безцінны, «з першых уст», од люди, якы жыли іщы на Лемковині закля «воля міцніжшых» іх одтамаль не выгнала. Гнеска юж ся ничого од них не довідаме. А Він вспіл. Знал, же треба ся понагляти, бо жытя втіче, а Лемкы якы іщы «дома» ся родили одходят штораз скорше і юж гнеска мало хто остал. А тоты, што іщы жыют, сут юж часто в марным стані або товды были іщы малы і невельо можут памятати. Зберал матерялы, слухал оповідань, ходил там на місци по Білцареві, зо старыма Білцаривянами. Зьвідувал ся о назвы тереновы і записувал.

Так єм си думал нераз, же не буду юж знал де єст «Сохів» (великій потик), де «Шкварлівка» (риля, на якій мешкала родина мого Няня), де «Бырлів», ци «Быча покута» - бо юж неє мі хто вказати. Жаль мі было, же єм з Няньом не поіхал до гір, жебы мі тото повказувал. Споро єм ся од него довідал і навет кусьцьок записал, але де што было в терені не знам і юж знал не буду, пропало. Тымчасом отверам першу окладинку i на розкладі назвы тереновы, а на задний окладинці на розкладі рилі. Втішыл єм ся незмірно. Не пропало. Хтоси задбал, хтоси записал. Хтоси іщы, подибні як мій Няньо, так кохал Білцареву і наш «Олімп» Дзелярку. Хтіл і потрафил. Вшытко тото коштувало вельо, і часу, і труду. Слава му за то! I за цілий двадцетрічний, як пише, труд над том книгом. Думам си, же нихто інчий не был бы в силі того в такій якости доконати, а коли бы прібувал, та люде бы му не помогли так, як Йому, завдякы Його позициі, Його заслугам для нашой культуры.

Задумал єм си, же найперше подам сухы, статистычны факты о Книзі..., а потим моі емоцйональны одчутя, але трудно ся оперти тенденциі до оціны, описуючы зміст.

Окрем розмаху выконаной працы, вражыня робят вспомнены юж выжше, выратуваны од забытя назвы тереновы, а тіж красетны фотографіі з оточыня села в розділі Географбія. Самого села, в значыню хыж, ци генеральніжше забудовы, не вказал (окрем церкви). І добри. Был єм в Білцареві коли село мало практычні іщы лемківску забудову. Было прекрасне. Коли зме вышли з Братми - якы мали товды по парунадцет років - на Дзелярку і на стоячу там іщы деревяну «патрию», як звали Лемкы вежу трянгуляцийну іщы з часив комасациі, та видок аж дых заперал в грудях. Хыжы серед садив были так вкомпонуваны в видок, же не лем не разили, але іщы были прикрасом. Гнеска там набудувано тых муруваных «кльоцків», часто по два, а быват і по три на єдным подвірци, та ся такє якісе чудне, брыдкє зробило, же не годен смотрити. На місци 
старой патриі єст модерна вежа видокова, але видок на село юж не тот. Зато вколо села краса тота сама, як видно на поміщеных в Книзі... знимках Петра Басалыґы.

Част історична задивлят не лем велькістю, але і часовым закресом, котрий зачынат ся од палєоліту, то єст старшой епокы камінной. Видно, же істория то «коник» Автора, же єй зна в степени, якым мало хто з докторатом може ся похвалити. Розділ тот є, в моім одчутю, вказаньом як бздурна єст польска теория о нашым нибы волоскым (румуньскым) походжыню. Приведу ту фрагмент з маргінесу на стороні 97, де в вельох жерелах єст поданий перший знаний з імена і назвиска шолтыс Білцаревы - Іван Труханович, а польска авторка, Кристина Перадзка, пише о ним Stanisław Truchanowicz. Ho a Stanisław то юж відомо чыє імено. Тот Іван єй выражні колов в очы і постановила го прекстити. Явні, можна бы речы - в жывы очы, бреше. Трохановскій пише іронічні: «Якє щестя, же мій записаний пращур мал імено Іван! Якого не даст ся „підіванити”». Імпонує в тий части кількіст жерел, през якы Автор мусіл ся «пребити», жебы мати такє знаня і такы цєкавосткы вынайти.

Інформаця о родинах, списы з давных жерел можут буд кому помочы найти і шліды своіх предків. Для прикладу подам што мене особисто дотычыло. Ведлуг мого Няня - жена мого прапрапрадіда Афтана называла же ся з дому Ференцяк. В Білцареві, з того што знам, не было Ференцяків. Не барз єм товды в тоту Ференцячку вірил, бо то навет для Няня давна давнина. Но, але, думал єм, може тот Афтан си взял жену споза Білцаревы. Тымчасом зо записив метрикальных з кінця XVIII столітя і зо списку на стороні 128 в тий книзі довідал єм ся, же были в нас Ференцякы. Выходит з того, же Афтан (якій же был з Богушы) приженил ся до Білцаревы до Ференцяків. Юж єст конкретна корыст з той книгы - знам, же Няньо повідал правду, яку знал од сестры свого діда.

Барз ня зачудувала част розділу Білцарівска еміррация - За Вельку Воду. Споро знам о Лемках, як і о тым, же емігрували до Америкы і де (менче більше) там мешкали. Єднак комплєтні ня заскочыла част названа Wolf Run - Волчий шлід або мала Білиарева в Аппаляхах. На західніх схылах Аппаляхів заложыли Лемкы село, якє звали «малом Лемковином», а якє Трохановскій назвал «малом Білцаревом», бо в декотрым часі было там 50\% Білцаривян. Другу половину становили Фльоринчане, Богушане, Камяняне, Брунаряне, Кунковяне і інчы. Видно як барз 
в чужым краю 3 «нелюдзком мовом» хтіли быти серед своіх. Інформациі сут обшырны. 3 мапком і списом назвиск. Єст тіж велика табеля зо списом Білцаривян в Америці, де мож поглядати свойой родины. Я нашол споро люди мойого родового назвиска і назвиска родового мойой Мамы, як тіж інчы родовы по стороні маминой Мамы, а мойой Бабці. Єст там тіж американьска знимка сестры мойой Бабці.

Дуже місця присьвачено обом сьвітовым войнам і часови меджевоєнному. Єст і спис, а навет 4 списы жытели нашого села в меджевойню (ріжнят ся мінімальні медже собом) і приписаня іх до окремых ріль. Єст навет мапка де чыя хыжа ся находила. Одручна і в кусьцьок здеформуваний скалі, але дає понятя о розміщыню хыж. Споро єст тіж архівальных знимок з тамтого часу.

Част історична кінчыт ся выселіньом, зо знаменным стверджыньом Автора, же «прешмарил» вельо літературы, в тым найновшой, але нигде в польскых жерелах не натрафил на буд якій шлід, найделикатнійше повівшы, сваволі на Лемковині в роках 1945-1947. Єст о тым в части Знатны люде - білцарівскы твориі во вспоминах тых люди (і не лем) і єст то важне сьвідоцтво.

Част о духовий, матеряльний і соспільний культурі зачынат ся прекрасным вступом Богдана Гамбаля і потим $є$ част газдивска. Хыжа (так при нагоді, нашол єм свого часу в словнику болгарско-польскым слово «хыжа» в подибным значыню як в нас) є описана на прикладі забудувань Владиміря Возняка, знатного Білцаривяна, уйка Автора. Опис жытя штоденного поданий єст попрез вспомины люди. Єден зо вспоминив припомнул мі Няньовы слова, же в селі росло дуже сливок. Няньо з тых сливок нагнал самогону на своє весіля. Іщы пред выселіньом посадил в саді 70 сливок, а як поіхал там в 60. (хыбаль) роках, та не было юж ани єдной. Вшыткы осадник вырубал. Дальше єст опис жытя пастушого, яри, літнього циклю, осени, зимы і робіт домовых, а тіж молотя в млинци, праня, управы лену, выробу гонтив, выробу масла. Потим є част Церков зо знимками білцаривской церкви і парох ікон (іконы сут і в інчых місцях). $€$ тіж листа парохів нашой церкви од 1752 рока. Дальше $є$ опис родинных обрядив, як весіля (зілюструване знимками рукопису Владиміря Возняка з описом весіля), хрестины і погріб. Тота част кінчыт ся описом дорічного сьваткуваня. Заміщене $є$ тіж пару сьпіванок і пісень церковных з нотами. На єденадцетьох сторонах додано знимкы крестив, капличок, хыж і вышываной запаскы. 
Част Знатны люде - білиарівскы твориі занимат вельо сторін не зато, жебы тых люди было аж так дуже (хоц і не мало - як на такє село), лем зато, же Автор хтіл тіж вказати приклады іх творчости. 3 описом той части мам кус проблєм, сут бо там і моі оповіданя, і творы мого Няня. Трудно товды заховати холодне, обєктывне пізріня. Генеральні помысл єст добрий, жебы презентувати творців попрез іх творы. Зачынат ся тота част од Андрия Трохановского з початку XIX столітя і веде аж до Олександра Козаренко з другой половины XX столітя - обнимат 23 назвиска. Серед них сут такы тузы, як Ярослав Качмарчык - премєр Уряду Руской Народовой Републикы Лемків (в сьвідомости Лемків, Президент). Майже каждий з них ма нотку єднакого обєму, незалежні од його значыня і доробку. I ту позволю си на дописаня пару речынь о Автори Книгь Біли,аревы:

Поета, прозаік і драматург, композитор (хоц він бы ся певні обрушыл на такє - от по просту написал музыку до кількоси там сьпіванок), соспільний діяч, вспілтворец і головний вспілорганізатор першых семох Лемківскых (іщы товды) Ватр в горах, вспілорганізатор і вспілведучий (іщы до недавна) Лемківской Ватры на Чужыні, головний редактор нашого двомісячника «Бесіда», диригент церковного хору, бывший член і соліста Ансамблю Пісні і Танця «Лемковина» (з прекрасным, потужным баритоном - а і басом, як треба было) і Староста його Рады, тлумач літературы славяньской, научытель релігіі і лемківской мовы, учасник чысленных русиньскых Конгресив, симпозиів, конференций (де лем ся розходит о нашы лемківскы справы), стріч поетыцкых в краю і за границьом, вспілорганізатор і вспілведучий Лемківской Творчой Осени, вспілавтор і головний вспілорганізатор Бєнналє Русиньской Культуры в Креници, лявреат поетыцкых нагород, неструджений пропагатор лемківской культуры на вельох імпрезах в краю і за границьом, одзначений Срібным Крестом Заслугы (якій рад бы замінити на кавальчык землі в Білцареві), автор Лемківского Букваря і збіркы верши для діти Мамко куn мі книжку, вспівавтор збіркы русиньской поезиі Русиньски/руски niснї Наталиі Дудаш з бывшой Югославіі (в єй части присьвачений Лемкам). Здибний рысовник і графік. І так бы певні можна было іщы гідні додати. 
О його Браті, Ярославі Трохановскым:

Маестро, граючий хыбаль на вшыткым, што му впало в рукы: на фортепяні, на акордеоні, на трубці, як треба та і на цимбалах, на басах, вйольончелі (басятах), а на гушлях впрост віртуоз. Любитель поезиі Івана Русенка (якого вершы потрафит деклямувати з памяти), композитор мельодий до його вершив і не лем. Мам для него велику пошану і вдячнист за створіня і проваджыня през довгы рокы Ансамблю Пісні і Танця «Лемковина» і за вспільне наше, майже 8 років в тым ансамблю, овінчене tourneе по Канаді і ЗША. Ансамбль сьпівал на 4 голосы і майже вшыткы мельодиі сам на тоты голосы розписувал. 3 огляду на нашу дяспору нагрывал окремы партиі на магнетофоновы касеты і давал членам, або пересылал почтом. Залюбений в наший Лемковині, вернул до ней не зважаючы на біду і всякы противности долі. То Його діяльнист започаткувала лемківскій ренесанс по райді «Лемковины» по Західній части Польщы. То під егідом Його «Лемковины» заістніла можливіст зорганізуваня в тамтых часах - коли на вшытко треба было мати позволіня власти - Лемківской Ватры в Чарний, під позором, же то «warsztaty plenerowe Zespołu „Łemkowyna”». Слава Ти за то друже Ярославе. Вартат тіж вспомнути, же мал і інчы таланты. Добри рысувал і малювал акварелями. Творил тіж оздобны деревяны тереликы з прекрасныма візерунками лемківскых церкви.

То тилько о знатных людях Білцаревы. Хто буде хтіл дашто більше о них знати - най зазрит до Книгы....

Остатній розділ, На выгнаню, обнимат листу преселеных так на Захід в 1947 р., як і скорше на всхід. На жаль листа всхідня є неповна. Барз бо трудно выдостати інформациі з краю, де люде жыли (і іщы певні часто жыют) в великым страху, а і по части юж на тилько ся вынародовили, же не памятают о своім родовым гнізді, або не хтят памятати (в нас ся тіж такє нерідко трафят). По части зас могли і не знати, же така Книга ся творит. То великій край, а люде розтрачены медже чужыма не мают доплыву інформциі з родинных гір. Представены сут в тий части цекавы документы родины Автора, як і листа Лемків, якы хтіли прехытрити комуністычны власти товдышньой Польщы. Отже был то час, коли в Польщи, під радяньскым натиском, прібувано впровадити колхозы (од росийского коллєктивное хозяйство). Люде за фраса не хтіли ся до того писати. Білцаривяне подумали, же як ся згодят на такій колхоз в Білцареві, та ім може позволят вернути. Написали лист до міністерства 
і залучыли листу охочых (наш Няньо тіж єй підписал). Єднак власти не дали ся на тото набрати. Тым барже, же то был юж рік 1959, коли в Польщи, по гомулковскій odwilży натиск на творіня колхозив міцно злекшал. Може як бы то были вчасніжшы рокы пятдесяты, коли комуністам барз залежало, жебы ся пред Сталіном похвалити сукцесами колєктывізациі, та бы ся ім скорше могло удати. Єст в тий части тіж споро знимок і зо Заходу, і зо всходу, а навет і з Канады.

Кінчыт ся попрез роздів В поклоні Дідам, Прадідам, якым зме поставили (мы - Білцаривяне) пропамятны кресты на обох цмонтерях, і реляцийом 3 іх посьвачыня. I зас ту Автор Книгъы... грал першы гушлі. Його авторства сут тексты на крестах, а здає ся, же і форма креста з назвисками білцаривскых Родив. I його підпис єст яко перший на просьбі до католицкого сьващенника о позволіня на поставіня тых памятників. Дальше єст юж лем Його реляция з того як Книга... ся родила, з сугестийом, же великє осувиско землі, якє трапит гнешніх жытели нашого села, то кара Божа за наше выгнаня.

$€$ то книга красота і незмірні цінна під кождым взглядом. Містит в собі барз дуже інформаций, якы ся тычат вшыткых Лемків, не лем з Білцаревы (зокрема розділ історичний - початковы його части) і з того взгляду може быти інтересуюча для каждого, незалежні з якого родового гнізда ся выводит його родина. В моій Родині вшыткы ся зачудували і вшыткы єй купили (декотры по пару примірників, бо як мало котра надає ся на презент).

Выпадало бы тіж написати дашто in minus, но але трудно ся до дачого причыпити. Можу лем повторити тото, што єм на горячо, сьвіжо по прочытаню, написал в е-майлю до Автора. Шкода, же не замістил барз важной мапкы, вказуючой де, в якы стороны нас Лемків розсіяно (так на Всхід, як і на Захід). Мапку тоту заміщено в «Лемківскым Річнику 2017». Поза тым іщы шкода, же в пару місцях тлумачыт ся, же дачого не зробил кус інакше, ліпше, шырше. Не барз можу си выобразити як мож бы «тото ци оне» зробити іщы ліпше, шырше, докладніжше. Юж тото, што єст то кольосальна робота, а коли бы хтіл іщы дашто «добавити», та нигда бы єй не скінчыл і не выдал друком, бо все мож дашто поправити і страта бы для нас была превелика. Знам, же то є такій кус ідеаліста, якій бы хтіл довершыти вшытко «до вершын», але то $є$ звычайні неможливе. Над такыма ділами працуют довгыма роками групы науковци. 
Не барз знам чого Трохановскій не замістил серед знатных Лемків Симеона Трохановского - посла до Сойму Крайового Галичыны I каденциі (1861-1867). Присьватил му што правда дуже місця (дві стороны 142143) в части описуючий австрийскій перйод нашой істориі, але я бым го окрем того вставил і в части Знатны люде..., хоцбы в формі одсылача до тамтых сторін. Был то бо непресічний Білцаривян.

В рецензиі Книгы Білиаревы тилько іщы вартало бы написати. По декотрых темах лем єм ся преслизнул, але мам надію, же єм кус приближл тот твір. Думам, же буду выразительом нас вшыткых, чытачив Книгы..., коли повім: крашні дякуєме друже, Петре. Желаме довгых років жытя в добрым здоровю і чекаме на дальшы творы. 